DOI 10.31558/2518-7953.2019.2.15

УДК 346.9

Д. В. Часовников, здобувач Донецького національного університету імені Василя Стуса

\title{
ПРАВОВА ОСНОВА ЗАСТОСУВАННЯ АДМІНІСТРАТИВНО-ГОСПОДАРСЬКИХ САНКЦІЙ ЗА ПРАВОПОРУШЕННЯ НА РИНКУ ЦІННИХ ПАПЕРІВ
}

Ключові слова: адміністративно-господарські санкиії, державне регулювання, штраф, правопорушення, нормативно-правові акти, ринок иінних паперів.

Найголовнішим елементом розвитку ринку цінних паперів $є$ його правове регулювання, яке забезпечує загальнообов'язковий регулятивний вплив на діяльність і поведінку всіх учасників зазначеного ринку. Цей компонент утворює необхідний нормативно-правовий базис, на якому учасники ринкових взаємовідносин, зокрема держава та ії̈ уповноважені органи, реалізують свої права, інтереси, обов'язки і повноваження [1].

Регулювання відносин на ринку цінних паперів здійснюється законодавством, що охоплює положення Конституції України, Господарського кодексу України (далі - ГК України), законів та підзаконних нормативно-правових актів, які встановлюють правила здійснення діяльності на цьому ринку, а також заходи відповідальності за порушення цих правил. Проте така нормативна база залишається недосконалою і суперечливою з огляду на невизначеність деяких ключових термінів та понять, неврегульованість окремих питань, неузгодженість та невпорядкованість певних норм, зокрема 3 питань застосування адміністративно-господарських санкцій за зазначені порушення.

Загальним питанням і проблемам щодо правових засад господарської діяльності, а також застосування господарських санкцій приділяли увагу такі науковці як В. К. Мамутов [2], Г. Л. Знаменський [3], В. С. Щербина [4], С. Ю. Гапало [5], О. А. Заярний [6], Н. М. Шевченко [7] та багато інших авторів. Питання регулювання ринку цінних паперів досліджувалися у наукових працях О. В. Бєлікової [8], Н. С. Кузнєцової [9], О. М. Мозгового [10], В. Л. Яроцького [11]. Окремо варто відзначити роботи О. В. Кологойди [12] та А. В. Попової [13], спеціально присвячені дослідженню питань господарсько-правової відповідальності за право- 
порушення на ринку цінних паперів. Водночас низка аспектів щодо правової основи застосування адміністративно-господарських санкцій за правопорушення на ринку цінних паперів на сьогодні потребують додаткового дослідження і опрацювання.

Наведене вище обумовлює актуальність теми цієї статті.

Метою статті є обгрунтування напрямів удосконалення правової основи застосування адміністративно-господарських санкиій за правопорушення на ринку циінних паперів.

Правова основа застосування адміністративно-господарських санкцій за правопорушення на ринку цінних паперів грунтується на Конституції України. Зокрема, це положення ст. 19 (правовий порядок в Україні грунтується на засадах, відповідно до яких ніхто не може бути примушений робити те, що не передбачено законодавством; органи державної влади та органи місцевого самоврядування, їхні посадові особи зобов'язані діяти лише на підставі, в межах повноважень та у спосіб, що передбачені Конституцією та законами України); ст. 58 (ніхто не може відповідати за діяння, які на час їхнього вчинення не визнавалися законом як правопорушення); ст. 92 (виключно законами України встановлюються: засади створення і функціонування фінансового, грошового, кредитного та інвестиційного ринків, порядок випуску та обігу державних цінних паперів, їхні види і типи; виключно законами України визначаються організація і діяльність органів виконавчої влади (п. 12 ч. 1), засади цивільно-правової відповідальності; діяння, які є злочинами, адміністративними або дисциплінарними правопорушеннями та відповідальність за них (п. 22 ч. 1) [14].

Джерелом регулювання цих відносин є також ГК України, який встановлює загальні положення щодо державного регулювання ринку цінних паперів (ст. 166), а також щодо відповідальності учасників господарських відносин, зокрема у формі застосування адміністративно-господарських санкцій. Серед таких положень: поняття та види адміністративно-господарських санкцій (ст.ст. 238-247); гарантії прав суб’єктів господарювання у разі неправомірного застосування до них адміністративно-господарських санкцій (ст. 249), строки застосування адміністративно-господарських санкцій (ст. 250) [15].

Ключовим нормативно-правовим актом, що регулює відносини у досліджуваній сфері, є Закон України «Про державне регулювання ринку цінних паперів в Україні» (далі - Закон про ДР РЦП). Цей Закон визначає правові засади здійснення державного регулювання ринку цінних паперів та державного контролю за випуском і обігом цінних паперів та їхніх похідних в Україні. Ним зокрема визначено терміни, що вживаються для цілей регулювання у відповідній сфері, мета та форми державного регулювання ринку цінних паперів, завдання та повноваження Національної комісії України з цінних паперів та фондового ринку (далі - 
НКЦПФР, Комісія), встановлено відповідальність юридичних осіб за правопорушення на ринку цінних паперів, передбачено кримінальну і майнову відповідальність за порушення законодавства про цінні папери, а також порядок застосування санкцій до юридичних осіб за правопорушення на цьому ринку [16]. Серед позитивних рис цього Закону потрібно відзначити охоплення ним більшості відносин, що мають місце при застосуванні адміністративно-господарських санкцій за порушення на ринку цінних паперів, а серед негативних можна виділити те, що перелік адміністративно-господарських санкцій, які застосовуються до учасників ринку цінних паперів, неупорядкований взагалі і потребує зведення його до певної внутрішньоузгодженої системи.

По-перше, положення про такі санкції розміщено в різних за змістом статтях цього Закону. Наприклал, положеннями ст. 11 Закону про ДР РЦП, що має назву «Відповідальність юридичних осіб за правопорушення на ринку цінних паперів», передбачено застосування санкції майнового характеру у вигляді штрафу (п. 1-17 ч. 1) та низки санкцій організаційно-правового характеру, а саме: зупинення або анулювання ліцензії на право провадження професійної діяльності на фондовому ринку, анулювання свідоцтва про реєстрацію об'єднання як саморегулівної організації фондового ринку. Поряд із цим ст. 8 Закону про ДР РЦП, яка має назву «Повноваження Національної комісії з цінних паперів та фондового ринку», передбачає й інші адміністративно-господарські санкції: зупинення обігу цінних паперів емітента (п. $5,5^{-1}$ ); заборона публічної пропозиції цінних паперів або допуск цінних паперів до торгів на фондовій біржі (п. $\left.16^{-4}\right)$; зупинення на підставі рішення Комісії внесення змін до системи реєстру власників іменних цінних паперів або до системи депозитарного обліку щодо цінних паперів певного емітента або певного власника (п. 30); заборона або обмеження депозитарних операцій (п. $\left.5^{-5}\right)$; зупинення торгівлі на фондовій біржі (п. 7); призупинення торгівлі цінними паперами (одного типу та класу) на фондових біржах $\left(\right.$ п. $\left.16^{-1}\right)$; заборона торгівлі цінними паперами (однакового типу та класу) на фондових біржах (п. 16-2); відкладення торгівлі цінними паперами (п. 16 $6^{-3}$; призначення тимчасово керівників фондових бірж, депозитаріїв та інших установ інфраструктури фондового ринку, зупинення або припинення допуску цінних паперів на фондові біржі або торгівлі ними на будь-якій фондовій біржі, зупинення клірингу та укладення договорів купівлі-продажу цінних паперів на фондових біржах (п.п. 15, 16); прийняття рішення про ліквідацію пайового інвестиційного фонду (п. 23); виключення уповноважених рейтингових агентств з Державного реєстру уповноважених рейтингових агентств, анулювання свідоцтва про включення до Державного реєстру уповноважених рейтингових агентств, виключення міжнародних рейтингових агентств з переліку визнаних (п. 29).

Окрім того, Указ Президента України «Про Національну комісію $з$ цінних паперів та фондового ринку» (далі - Указ про НКЦПФР) зараховує до повнова- 
жень Комісії право застосування додаткових санкцій, невизначених Законом про ДР РЦП: прийняття рішення про ліквідацію закритого корпоративного інвестиційного фонду; вирішення питання щодо зупинення розміщення та викупу цінних паперів інституту спільного інвестування; вжиття заходів щодо призупинення подальшого розміщення іпотечних сертифікатів; призупинення емісії іпотечних сертифікатів на будь-якому її етапі до етапу розкриття інформації; застосовування до суб'єктів первинного фінансового моніторингу у разі невиконання (неналежного виконання) вимог Закону України «Про запобігання та протидію легалізації (відмиванню) доходів, одержаних злочинним шляхом, або фінансуванню тероризму» та / або нормативно-правових актів, що регулюють діяльність у сфері запобігання та протидії легалізації (відмиванню) доходів, одержаних злочинним шляхом, або фінансуванню тероризму, фінансові санкції, обмеження, тимчасове припинення дії чи анулювання ліцензії [17].

По-друге, всупереч положенням п. 22 ч. 1 ст. 92 Конституції України та п. 2 ст. 238 ГК України, в більшості випадків це стосується санкцій організаційноправового характеру, Закон про ДР РЦП взагалі не визначає умови і підстави їхнього застосування. Виняток становлять лише санкції за маніпулювання на фондовому ринку (ст. $10^{-1}$ ) та санкція стосовно призначення тимчасового адміністратора професійного учасника депозитарної системи України (ст. 112).

Що ж до інших санкцій організаційно-правового характеру, то підстави і умови для їхнього застосування визначені підзаконними нормативно-правовими актами НКЦПФР. Наприклад, Рішення НКЦПФР № 393 від 30.05.2017 р. «Про затвердження Положення про встановлення ознак фіктивності емітентів цінних паперів та включення таких емітентів до списку емітентів, що мають ознаки фіктивності» для санкції у вигляді зупинення обігу цінних паперів емітента; Рішення НКЦПФР № 424 від 21.06.2018 р. «Про затвердження Положення про здійснення публічної пропозиції цінних паперів» при забороні публічної пропозиції цінних паперів або допуску цінних паперів до торгів на фондовій біржі; Рішення НКЦПФР № 816 від 14.05.2013 р. «Про затвердження Порядку зупинення дії та анулювання ліцензії на окремі види професійної діяльності на фондовому ринку (ринку цінних паперів)» при зупиненні дії ліцензії, анулюванні ліцензії на здійснення професійної діяльності на ринку цінних паперів; Рішення НКЦПФР № 607 від 10.08.2017 р. «Про затвердження Положення про порядок проведення конкурсу з визначення уповноважених рейтингових агентств та порядок ведення Державного реєстру уповноважених рейтингових агентств» при здійсненні заходів щодо виключення уповноважених рейтингових агентств з Державного реєстру уповноважених рейтингових агентств; Рішення НКЦПФР № 1925 від 27.12.2012 р. «Про затвердження Положення про об'єднання професійних учасників фондового ринку» при анулюванні свідоцтва про реєстрацію об’єднання як саморегулівної ор- 
ганізації фондового ринку, при виключенні міжнародних рейтингових агентств 3 переліку та інші рішення.

В окремих випадках Закон про ДР РЦП містить абстрактні норми-принципи, наприклад: у разі порушення законодавства про цінні папери та / або нормативних актів НКЦПФР виносити попередження (п. 5 ст. 8); у разі порушення фондовою біржою законодавства про цінні папери, статуту та правил фондової біржі зупиняти торгівлю на фондовій біржі до усунення таких порушень (п. 7 ст. 8); порушувати питання про звільнення з посад керівників фондових бірж та інших установ інфраструктури фондового ринку у випадках недодержання ними чинного законодавства України, для захисту інтересів інвесторів та громадян (п. 15 ст. 8). Аналогічні положення наявні і в Указі про НКЦПФР: порушувати задля захисту інтересів інвесторів та громадян питання про звільнення з посад керівників фондових бірж та інших установ інфраструктури фондового ринку у разі недодержання ними чинного законодавства України (пп. 65 п. 5).

Аналіз положень ст. 11 Закону про ДР РЦП щодо майнових санкцій у вигляді штрафу дає змогу зробити висновок про необхідність законодавчого уточнення таких питань. Так, доопрацювання потребує ч. 1 ст. 11, якою у ряді випадків при застосуванні штрафів передбачено положення «...за ті самі дії, вчинені повторно протягом року», водночас, Закон про ДР РЦП, як і інші нормативноправові акти, що регулюють відносини на ринку цінних паперів, не визначає, які саме дії кваліфікуються як повторні та з якого моменту починається перебіг часу для повторності, що на практиці призводить до їх неоднакового розуміння та застосування.

Також потребують термінологічної єдності та визначеності поняття фінансових санкцій та штрафних санкцій, що наведені в Законі про ДР РЦП та Указі про НКЦПФР.

Нагальною вбачається конкретизація механізму використання положень п.П. 1, 11, 12 ч. 1 ст. 11 Закону про ДР РЦП, а саме: доцільно конкретизувати, за яких умов за визначені правопорушення на ринку цінних паперів застосовуються санкції із розрахунку неоподатковуваних мінімумів доходів громадян, а в якому випадку - у відсотках прибутку (надходжень), одержаних у результаті протиправних дій.

Суперечливою також є і доцільність застосування санкції за схожі за змістом правопорушення, як-от: ненадання інвестору в цінні папери (зокрема акціонеру) на його письмовий запит інформації про діяльність емітента в межах, передбачених законом (п. 3 ч. 1 ст. 11) та несвоєчасне надання інформації інвесторам в цінні папери на їхній письмовий запит (п. 4 ч. 1 ст. 11). Слушною у цьому випадку є висловлена судом при розгляді однієї зі справ позиція, згідно з якою зміст поняття «неподання» розуміється зокрема як неподання відповідної інформації у встановлений термін [18, 19]. 
Вбачається, що застарілими є положення ч. 1 ст. 11 Закону про ДР РЦП, а саме: п. 5 (неопублікування, опублікування не в повному обсязі інформації та / або опублікування недостовірної інформації); п. 6 (нерозміщення, розміщення не в повному обсязі інформації та / або розміщення недостовірної інформації у загальнодоступній інформаційній базі даних НКЦПФР про ринок цінних паперів); п. 7 (неподання, подання не в повному обсязі інформації та / або подання недостовірної інформації до НКЦПФР). Зазначене зауваження обумовлене тим, що згідно з останніми змінами законодавства про цінні папери скасовано обов’ язкове опублікування інформації на ринку цінних паперів взагалі. Крім того, санкції за п.п. 5-7 по суті застосовуються за однією загальною підставою - за невиконання норм законодавства про цінні папери стосовно розкриття інформації.

3 урахуванням наведеного вище для уникнення дуалізму і неоднакового регулювання одних і тих самих відносин доцільним видається внесення змін до ст. 11 Закону про ДР РЦП шляхом об'єднання в один пункт п.п. 5-7 ч. 1 з викладенням його в такій редакції: «нерозкриття інформації на ринку цінних паперів у строки, установлені відповідними законодавчими актами, розкриття не в повному обсязі та / або розкриття недостовірної інформації».

Як вже зазначалося, у правовому регулюванні застосування адміністративногосподарських санкцій на ринку цінних паперах певне місце належить рішенням НКЦПФР, з-поміж яких і Правила розгляду справ про порушення вимог законодавства на ринку цінних паперів та застосування санкцій, затверджені рішенням НКЦПФР від 16.10.2012 р. № 1470 (далі - Правила 1470), які визначають порядок та строки розгляду Комісією справ про порушення громадянами, посадовими особами та юридичними особами вимог законодавства на ринку цінних паперів [20]. Для усунення повторів та нагромадження норм потребують виключення з Правил 1470 розділи IX-XIII, які регулюють питання провадження у справах про порушення громадянами, посадовими особами законодавства на ринку цінних паперів (адміністративні правопорушення), оскільки ці норми по суті повторюють норми Кодексу України про адміністративні правопорушення.

Окрім того, загальні положення Правил 1470 потребують доопрацювання, тому що визначають порядок та строки розгляду НКЦПФР справ про порушення юридичними особами при застосуванні санкцій, наведених лише у ст. 11 Закону про ДР РЦП. Проте, як вже було зазначено вище, статті Закону про ДР РЦП та Указу про НКЦПФР містять норми стосовно й інших адміністративно-господарських санкцій. Отже, до загальних положень Правил 1470 необхідно або додати положення про поширення їх на всі види санкцій, що застосовуються уповноваженим державним органом на РЦП, або внести до Правил 1470 застереження, що його норми не поширюються на правовідносини, що виникають при застосуванні певних особливих санкцій, передбачених законодавством про цінні папери. 
Досить актуальним на сьогодні є і питання спрощення процедури розгляду справ про правопорушення, визначене Правилами 1470 стосовно юридичних осіб. Дослідивши суспільні відносини, що врегульовані аналогічними нормами, дія яких поширюється на сфери ринку фінансових послуг, державного контролю на автомобільному транспорті, антимонопольного, зовнішньоекономічного законодавства, можна дійти висновку про доцільність виключення стадії порушення провадження (винесення постанови про порушення справи про правопорушення на ринку цінних паперів), оскільки вона за своїм змістом повторює стадію складання акту про правопорушення. До того ж Закон про ДР РЦП не містить положень про обов'язковість складання постанови про порушення справи про правопорушення на ринку цінних паперів, а визначає, що Уповноважена особа НКЦПФР, яка виявила факт вчинення юридичною особою правопорушення на ринку цінних паперів, складає акт про правопорушення.

Отже, основними напрямами удосконалення правової основи застосування адміністративно-господарських санкцій за правопорушення на ринку цуіних паперів можуть бути:

1) на рівні Закону про ДР РЦП - систематизація положень (які нині розрізнено закріплено різними нормативно-правовими актами) щуодо видів адміністративно-господарських санкиій за правопорушення на ринку ичінних паперів, підстав та умов їхнього застосування; в окремих випадках зменшення рівня абстрактності змісту загальної норми шляхом більш чіткого і змістовного відображення підстав та умов застосування таких санкиій; закріплення визначення понять «фінансових санкиій та штрафних санкцій»; конкретизація механізму використання положень щчодо: розрахунку при застосуванні санкцій у неоподатковуваних мінімумах доходів громадян та/або у відсотках прибутку (надходжень), одержаних внаслідок протиправних дій; конкретизація положень стосовно «дій, вчинених повторно протягом року»; здійснення перегляду застарілих норм та повторів відносно майнових санкиій у вигляді штрафу;

2) на рівні підзаконних нормативно-правових актів - усунення нагромадження нормами, які регулюють питання провадження у справах про порушення громадянами, посадовими особами законодавства на ринку цінних паперів; спрощчення процедури розгляду справ про правопорушення на ринку иінних паперів стосовно юридичних осіб; доопрацювання порядку розгляду справ про правопорушення на ринку цінних паперів щуодо юридичних осіб з урахуванням усіх наявних видів адміністративно-господарських санкцій; виключення положень, щзо встановлюють підстави та умови застосування адміністративно-господарських санкиій.

Внесення запропонованих змін до нормативно-правових актів та проведення додаткових наукових досліджень з окремих проблемних питань нормативно-пра- 
вового регулювання фондового ринку України сприятиме прискоренню розвитку організованого фондового ринку в Україні, що зі свого боку може позитивно вплинути на рівень довіри до українських цінних паперів, на їхню ліквідність, капіталізацію ринку, сприятиме збільшенню прибутків як інвесторів, так і бюджету.

1. Білозір М. Р. Принципи регулювання ринку цінних паперів. Стратегічні орієнтири. URL: http://libfor.com/index.php?newsid=3438

2. Хозяйственное право: учебник / под общ. ред. В. К. Мамутова. Киев: Юринком Интер. 2002. 912 c.

3. Знаменский Г. Л. Хозяйственное законодательство Украины: формирование и перспективы развития. Київ: Наукова думка. 1996. 56 с.

4. Щербина В. С. Господарсько-правова відповідальність у доктрині господарського права України та її законодавче закріплення. Право України. 2019. № 8. С. 81-93.

5. Гапало С. В. Санкції в господарському праві України: автореф. дис. ... канд. юрид. наук: 12.00.04. Київський нац. економ. ун-т ім. Вадима Гетьмана. Київ, 2011. 20 с.

6. Заярний О. А. Відповідальність в організаційно-господарських відносинах: автореф. дис. ... канд. юрид. наук: 12.00.04. Київський нац. ун-т ім. Тараса Шевченка. Київ, 2011. 18 с.

7. Шевченко Н. М. Адміністративно-господарські санкції в системі правової охорони. Актуальні проблеми держави і права. 2005. № 25. С. 317-321.

8. Бєлікова О. В. Фінансово-правове регулювання ринку цінних паперів в Україні: автореф. дис. ... канд. юрид. наук: 12.00.07. Класичний приватний ун-т. Запоріжжя, 2011. 20 с.

9. Кузнєцова Н. С., Назарчук І. Р. Ринок цінних паперів в Україні: правові основи формування та функціонування. Київ: Юрінком Інтер, 1998. 528 с.

10. Мозговий О. М. Формування системи регулювання фондового ринку України (методологія і організація): автореф. дис. ... д-ра екон. наук: 08.04.01. Київський нац. економ. ун-т. Київ, 1999. 33 с.

11. Яроцький В. Л. Цінні папери в механізмі правового регулювання майнових відносин (основи інструментальної концепції): моногр. Харків: Право. 2006. 544 с.

12. Кологойда О.В.Адміністративно-господарські санкцій за недоговірні правопорушення на фондовому ринку. Адміністративне право і проиес. 2014. № 3(9). С. 118-132.

13. Попова А. В. Господарсько-правова відповідальність професйних учасників ринку цінних паперів. Університетські наукові записки. 2005. № 3(15). С. 159-164.

14. Конституція України від 28 червня 1996 р. Відомості Верховної Ради Украӥни. 1996. № 30. Ст. 141.

15. Господарський кодекс України: Закон України від 16 січня 2003 р. Відомості Верховної Ради України. 2003. № 18. Ст. 144.

16. Про державне регулювання ринку цінних паперів в Україні: Закон України від 30 жовтня 1996 р. № 448/96-ВР. Відомості Верховної Ради Украӥни. 2003. № 51. Ст. 292.

17. Про Національну комісію $з$ цінних паперів та фондового ринку: Указ Президента України від 23 листопада 2011 р. № 1063/2011. Офіиійний вісник України. 2011. № 94. Ст. 18.

18. Постанова Донецького окружного адміністративного суду від 15 лютого 2013 р. у справі № 2a/0570/17498/2012. Сдиний державний реєстр судових рімень. URL: http://reyestr. court.gov.ua/Review/29569575 (дата звернення: 11.11.2019).

19. Ухвала Донецького апеляційного адміністративного суду від 21 березня 2013 р. у справі № 2a/0570/17498/2012. Єәиний державний реєстр судових рішень. URL: http://reyestr. court.gov.ua/Review/30195824 (дата звернення: 11.11.2019).

20. Правила розгляду справ про порушення вимог законодавства на ринку цінних паперів та застосування санкцій: затвердж. Рішенням НКЦПФР від 16 жовтня 2012 р. № 1470. Офіціийний вісник Украӥни. 2012. № 87. Ст. 207. 